\title{
Kaposi Sarcoma: Changing Trend in Calabar, SOUTH EASTERN NIGERIA
}

\author{
${ }^{1}$ M. E. Asuquo, ${ }^{1}$ A. Ogunkeyede, ${ }^{2}$ E. E. Bassey and ${ }^{2}$ G. Ebughe \\ Departments of ${ }^{1}$ Surgery and ${ }^{2}$ Pathology University of Calabar Teaching Hospital, Calabar, Nigeria \\ Reprint requests to: DR. M. E. Asuquo, G. P. O. Box 1891, Calabar, Nigeria.E-mail: mauefas@yahoo.com
}

\begin{abstract}
Background/objective: Kaposi sarcoma (KS) is now the most frequently reported malignant skin tumour in some areas of Africa and was endemic in Africa before the advent of the human immunodeficiency virus (HIV) infection. The prevalence has increased with the emergence of HIV infection. The objective of this report is to describe the frequency, current clinical pattern, and anatomic distribution of KS in Calabar, south-eastern Nigeria and compare this with total malignant skin tumour.

Method: All the patients with histologic diagnosis of KS presenting to the University of Calabar Teaching Hospital from January 2005 and December 2006 were analyzed as part of the wider study of malignant skin tumorus. Diagnosis of HIV was based upon enzyme linked immunosorbent assay.

Results: In our study, there were 11 patients ( 7 males and 4 females), with a male: female ratio of 1.75: 1. This was the commonest malignant skin tumor (38\%) followed by squamous cell carcinoma (SCC) (34.5\%) and the age ranged from 21 - 60 years (mean 42.9years). Nine patients (81.8\%) were HIV positive including the 4 females (age ranged from 21 -45 years) and 2(18.2\%) HIV negative, aged 59 and 60 years. The lower limb was the commonest site (50\%). Atypical lesions involved the eyelids/ nose and penis.

Conclusion: KS is now the commonest malignant skin tumour in our region with the HIV related KS as the commonest clinical type. Successful prevention and treatment of HIV infection would reduce the prevalence of this tumour.
\end{abstract}

Key words: Kaposi sarcoma, trend, HIV

\begin{abstract}
Résumé
Contexte: Le sarcome de Kaposi est à l'heure actuelle la plus fréquente des tumeurs malignes cutanées dans certaines zones d'Afrique. Il sévissait à l'état endémique avant l'avènement de l'infection par le virus de l'immunodéficience humaine (VIH). La prévalence s'est accrue avec l'émergence l'infection par le VIH. L'objectif de ce travail est de décrire la fréquence, le mode de présentation clinique usuel, et la distribution anatomique du sarcome de Kaposi à Calabar dans le Sud-est du Nigeria et de procéder a une comparaison avec l'ensemble des tumeurs malignes cutanées.

Méthode: Tous les patients ayant un sarcome de Kaposi confirme histologiquement et ayant consulte au Centre Hospitalier Universitaire de Calabar de janvier 2005 a décembre 2006 ont été considéré comme un échantillon de la population des tumeurs malignes cutanées. Le diagnostic de l'infection VIH était base sur la technique ELISA.

Résultats: Notre étude comptait 11 patients ( 7 hommes et 4 femmes), avec un sexe ratio homme femme de 1,75. Il s'agissait de la tumeur maligne cutanée la plus fréquente (38\%) suivi par le carcinome a cellule squameuses (34,5\%). L'âge variait de 21 a 60 ans pour une moyenne de 42,9 ans. Neuf patients $(81,8 \%)$ était séropositifs y compris les 4 femmes 9age allant de 21 à 45 ans). Deux patients âgés respectivement de 59 et de 60 ans étaient séronégatifs. La localisation la plus fréquente était le membre inferieur (50\%); les lésions atypiques concernaient les paupières, le nez et le pénis.
\end{abstract}


Conclusion: Le sarcome de Kaposi est de nos jours la plus fréquente des tumeurs malignes cutanées dans notre région et sa forme associée au VIH est le type clinique le plus courant. Une prévention efficace et le traitement de l'infection VIH pourrait réduire la prévalence de cette tumeur

Mots clés: Sarcome de Kaposi, mode de présentation, VIH

\section{Introduction}

Kaposi sarcoma is now the most frequently reported malignant skin tumour in some areas of Africa and was endemic in Africa even before the advent of the human immunodeficiency virus (HIV). ${ }^{1,2}$ There are 4 clinical types of KS: Classic, African (endemic), immunosuppressive (transplant) associated and Acquired immuno-deficiency syndrome (AIDS) associated KS with identical histological features. ${ }^{3}$ Since the emergence of HIV infection there has been a steady increase in the prevalence of KS worldwide. ${ }^{4}$ In Nigeria, with an adult seroprevalence ratio of $5.8 \%$, this disease is a major cause of morbidity and mortality. ${ }^{5}$ In an earlier study in this center, there was no convincing evidence that the disease was associated with HIV infection. ${ }^{6}$ This is a report of the changing trend of KS in the same center.

\section{Patient and Methods}

Patients who had histologic diagnosis of Kaposi sarcoma in the University of Calabar Teaching Hospital (UCTH), Calabar from January 2005 December 2006 as part of our prospective study of malignant skin tumours were studied. This was compared with KS seen from 2000 - 2004 and total malignant skin tumour (2005-2006). Serology test for HIV antibodies were performed using the enzyme linked immunosorbent assay (ELISA).

\section{Results}

There were 11 patients ( 7 males and 4 females) with a $M: F$ ratio of $1.75: 1$, this accounted for $38 \%$ of malignant skin tumours seen during this study period. Squamous cell carcinoma (SCC) ranked 2nd with 10 patients (34.5\%) (Table 1). In an earlier study of malignant skin tumours in this hospital (2000 2004), KS ranked $2^{\text {nd }}(27 \%)$ following SCC (37\%). The ages ranged from 21 - 60 years, (mean 42.9years) (Table 2). Nine patients (81.8\%) were HIV positive, their ages ranged from 21 - 45years and 2(18.2\%) HIV negative, aged 59 and 60years. All the patients were heterosexuals who presented late in hospital after prior traditional herbal treatment for periods that ranged from six months and 10 years.

Single $3(27.3 \%)$ and multiple $8(72.7 \%)$ sites were involved in various combinations resulting in the lower limb as the commonest site $8(50 \%)$. Others were the face; $2(12.5 \%)$, (Figure 1), trunk, 2(12.5\%) and lymph node $2(12.5 \%)$, upper limb in a patient and the penis in another, (Figure 2 ) in a patient each (Table 3).

The two patients (18.2\%) with African KS received systemic chemotherapy (vincristine) with regression of nodules, follow-up were 12 and 18months. Four patients $(36.3 \%)$ serology positive were lost to follow-up after histologic diagnosis. Four patients (36.3\%) serology positive had antiretroviral therapy (ART) with systemic chemotherapy (vincristine). Out of these two were still being observed in the outpatient with regression of the nodules. Follow-up has been for 6 and 8months. Two patients with localized lesions, eyelid and chronic toe ulcer with deformity had excision and amputation respectively. There was one hospital mortality in a male HIV positive patient. The fungating lesions were dressed with honey and antibiotics administered based on sensitivity, the common isolates were Staphylococcus aureus pseudomonas and proteus.

Table 1. Skin cancers in 29 patients in Calabar, South-eastern Nigeria

\begin{tabular}{llll}
\hline Tumour type & Sex & & Total (\%) \\
\hline & $\mathrm{M}$ & $\mathrm{F}$ & $11(37.9)$ \\
Kaposi sarcoma & 7 & 4 & $10(34.5)$ \\
Squamous cell carcinoma & 6 & 4 & $4(13.8)$ \\
Malignant melanoma & 2 & 2 & $2(6.9)$ \\
Metastatic skin cancer & 1 & 1 & $1(3.4)$ \\
Basal cell carcinoma & - & 1 & $1(3.4)$ \\
Malignant adnexal tumor & - & 1 & $29(100)$ \\
\hline Total & 16 & 13 & \\
\hline
\end{tabular}


Table 2. Age and sex distribution of 11 patients with Kaposi's sarcoma

\begin{tabular}{|c|c|c|c|}
\hline Age (years) & Sex & & Total (\%) \\
\hline & $M$ & $\mathrm{~F}$ & \\
\hline$\leq 10$ & - & - & - \\
\hline $11-20$ & - & - & - \\
\hline $21-30$ & - & 2 & $2(18.2)$ \\
\hline $31-40$ & 2 & 1 & $3(27.3)$ \\
\hline $41-50$ & 2 & - & $2(18.2)$ \\
\hline $51-60$ & 3 & 1 & $4(36.3)$ \\
\hline Total & 7 & 4 & $11(100)$ \\
\hline
\end{tabular}

Table 3. Anatomical distribution of Kaposi sarcoma in 11 patients

\begin{tabular}{llll}
\hline Region & Seropositive & Seronegative & Total \\
\hline Face (Eyelid/ nose) & 2 & - & 2 \\
Upper limb & 1 & - & 1 \\
Trunk & 2 & - & 2 \\
External genitalia (penis) & 1 & - & 1 \\
Lymph node (inguinal) & 2 & - & 2 \\
Lower limb & 6 & 2 & 8 \\
\hline
\end{tabular}

Figure 1. Kaposi sarcoma involving the eyelids and nose

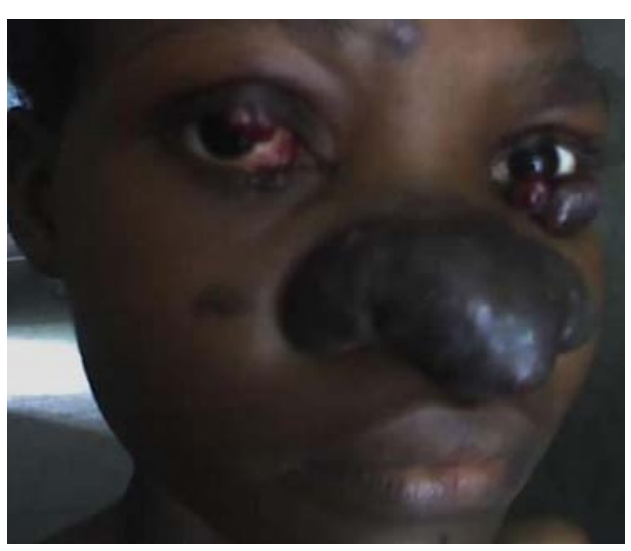

Figure 2. Kaposi sarcoma involving the penis

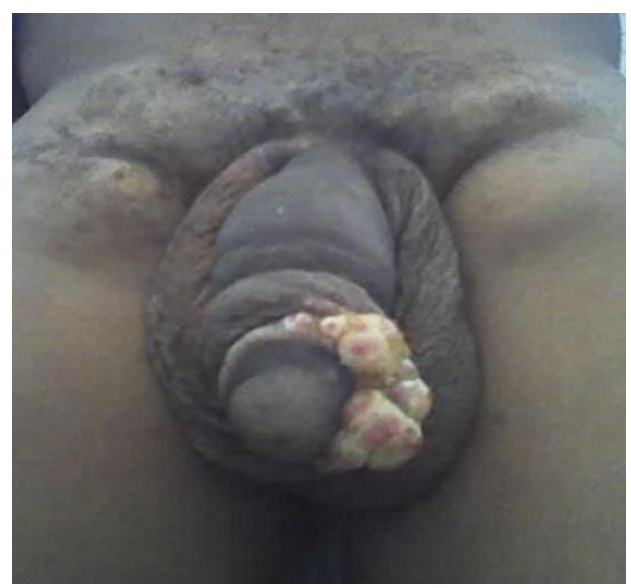

\section{Discussion}

We report an increased prevalence of $\mathrm{KS}$ in our region. It was the commonest malignant skin tumour that accounted for $38 \%$ of total malignant skin tumours, SCC ranked 2nd (34.5\%) in this study compared to a previous one in this center where KS ranked 2nd (27\%) following SCC (37\%). ${ }^{7}$ In Kano northern Nigeria, KS was the 4th most prevalent malignant skin tumour (8\%) ${ }^{8}$ and in Maiduguri northern Nigeria $16 \%{ }^{9}$

Our findings showed that KS was HIV-related in $81.8 \%$ while African (endemic) KS was recorded in $18.2 \%$ of patients. The cases of KS documented by histology do not represent all the cases of KS seen as most patients with clinical suspicion did not have histopathologic diagnosis. However, this was at variance with an earlier publication from this center which suggested that KS was not related to HIV infection. ${ }^{6}$ This current clinical pattern of KS seen is in keeping with reports from Nigeria and other African countries affected by HIV epidemic. ${ }^{5,10}$

Kaposi sarcoma was predominantly a disease of men in both the black and white. ${ }^{3}$ However, in our study there were 7 males and 4 females (male: female 1.75: 1). Onunu et al in Benin - Nigeria reported a M: F ratio of 1.6: 1 . $^{5}$ This is contrary to previous Nigerian studies that reported the occurrence of KS exclusively in men. ${ }^{6}$ It is also note worthy that all the females in this study were HIV positive and one presented with atypical lesions involving the eyelids and nose (Figure 1). 
It is noteworthy that with the advent of HIV infection more females were involved contrary to previous studies with mainly endemic KS as the clinical type that involved mainly men, Wabinga et al reported in endemic KS a M: F ratio of 15: $1 .^{11}$ Atypical lesions (Figures 1 and 2) should arouse the suspicion of HIV.

The HIV related $\mathrm{KS}$ in this study affected young adults aged 21 - 45years whereas the endemic KS were aged 59 and 60years. HIV related KS has been known to affect younger patients than the other clinical types. ${ }^{12}$

Ignorance, poverty and socio-cultural beliefs were underlying issues as most patients presented late after prior traditional medical treatment and there after some were lost to follow-up for fear of stigmatization.

In conclusion, this study demonstrated the changing trend of KS in our region. It revealed that HIV related KS is now more common especially in young adults than endemic KS and that atypical lesions should arouse the suspicion of HIV infection. KS is more likely to be seen in women with HIV positivity. Successful prevention and treatment of HIV infection would result in a decline in the prevalence of this tumour with improved outcome.

\section{References}

1. Stein ME, Spencer D, Ruff P, Lakier R, MacPhail P, Bezwoda WR. Endemic African Kaposi sarcoma: clinical and therapeutic implications, 10-year experience in Johannesburg Hospital (19801990). Oncology. 1994; 51:63-69.

2. Sitas F, Pacella-Norman $\mathrm{R}$, Carrara $\mathrm{H}$, et al.
Spectrum of HIV- I related cancers in South Africa. Int J Cancer. 2000; 88:489-492.

3. Antman K, Chang Y. Kaposi sarcoma. N Engl J Med. 2000; 342:1027-1038.

4. Mandong BM, Chirdan LB, Anyebe AO, Mannaseh AN. Histopathological study of Kaposi's sarcoma in Jos: A 16 year review. Ann Afr Med. 2004; 3:174-176.

5. Onunu AN, Okoduwa C, Eze EU, Adeyekun AA, Kubeyinje EP, Schwartz RA. Kaposi's sarcoma in Nigeria. Int J Dermatol. 2007; 46:264-267.

6. Otu AA. Kaposi's sarcoma clinical, immunological and therapeutic considerations. Nigerian Medical Practitioner. 1990; 19:87-92.

7. Asuquo ME, Agweye P, Ugare G, Ebughe G. Basal cell carcinoma in five albino Africans from the south-eastern equatorial rain forest of Nigeria. Int J Dermatol. 2007; 46:754-756.

8. Ochicha O, Edino ST, Mohammed AZ, Umar AB. Dermatological malignancies in Kano, Northern Nigeria. A histopathological review. Ann Afr Med. 2004; 3:188-191.

9. Nggada HA, Na'aya HU, Ali N. A histological analysis of malignant tumours of the skin in University of Maiduguri Teaching Hospital, Nigeria. Highland Medical Research Journal. 2003; 1:38-40.

10. Mohammed AZ, Nwana EJC, Mannaseh AN. Changing patterns of Kaposi's sarcoma in Nigeria. Trop Doct. 2005; 35:168-169.

11. Wabinga HR, Parkin DM, Wabwire-Mangen F, et al. Cancer in Kampala, Uganda in 1989 -1991: changes in incidence in the era of AIDS. Int J Cancer. 1993; 54:26-36.

12. Bayley AC. Aggressive Kaposi's sarcoma in Zambia, 1983. Lancet. 1984; 1:1318-1320. 